SEHATI

Jurnal Kesehatan
Vol 1, No 2, Agustus 2021, p. 63-72

e-ISSN : 2775-6963 | p-ISSN : 2775-6955

DOI: https://doi.org/10.52364/sehati.v1i2.7

RESEARCH ARTICLE

OPEN ACCESS

\title{
Analisis faktor lingkungan terhadap kejadian kecacingan pada murid Sekolah Dasar di Kelurahan Seberang Tembilahan Kabupaten Indragiri Hilir
}

\author{
Paridah $^{1}$, Zahtamal ${ }^{2}$, Ridwan Manda Putra ${ }^{3}$ \\ ${ }^{1,3}$ Program Magister Ilmu Lingkungan Universitas Riau \\ ${ }^{2}$ Fakultas Kedokteran Universitas Riau \\ *Correspondent email : paridah43e@yahoo.com \\ Diterima: 12 Agustus 2021 | Disetujui: 30 Agustus 2021 | Diterbitkan: 31 Agustus 2021
}

\begin{abstract}
This study aims to analyze the influence of physical environmental factors (clean water facilities, latrine conditions, SPAL conditions, type of house floor, household waste management), economic factors (family income) and social environmental factors (nail hygiene, use of footwear, washing habits hands with soap, bowel habits) against helminthiasis in elementary school students in Seberang Tembilahan Village, Indragiri Hilir Regency. The research location was conducted in Seberang Tembilahan Sub-District, Indragiri Hilir Regency in January to February 2020. The study used a survey method. The analytical method used is univariate analysis, bivariate analysis with Chi Square (Fisher) and multivariate analysis with logistic regression. The results of the study of 72 elementary school students in 4 elementary schools who were examined by laboratory feces, found positive results of worm infestation of $23.61 \%$ or 17 students. The final results of the model test showed that although the clean water facilities and toilet conditions were not significant, the two variables influenced each other, it was possible that there was an interaction between the two variables in influencing the incidence of helminthiasis in elementary school students. The variable that most affected the incidence of helminthiasis in elementary school students was the latrine condition with adjusted $O R$ of 4.01 so that respondents whose conditions did not meet the requirements were 4.01 times more likely to experience helminthiasis compared to conditions that were eligible after being controlled by other variables. Simultaneously the two variables (clean water facilities and latrine conditions) can explain the variation of helminthiasis in elementary students by $9.9 \%$.
\end{abstract}

Keywords: Physical Environmental; Economic; Social Environmental; and Worm Infection

Penyakit cacingan merupakan salah satu masalah utama kesehatan dan menjadi ancaman masyarakat dunia, salah satu diantaranya adalah kecacingan. Kejadian kecacingan dapat mengakibatkan menurunnya kondisi kesehatan, gizi, kecerdasan dan produktivitas penderita, dan secara ekonomi banyak menyebabkan kerugian, sehingga menurunkan kualitas sumber daya manusia, diantara kejadian kecacingan, kejadian cacingan yang terpenting adalah cacing gelang (Ascaris lumbricoides), cacing cambuk (Trichuristrichiura $s p$ ) dan cacing tambang (Necator americanus dan Ancylostoma duodenale) karena jenis cacing ini yang paling banyak menginfestasi manusia (Kemenkes RI, 2006)

Data Dinkes Kabupaten Indragiri Hilir Tahun 2018 menunjukkan kasus kecacingan dari 27 Puskesmas tercatat 3.365 kasus, dengan 432 kasus terdapat di Puskesmas Tembilahan Kota. Hasil survei kecacingan oleh Dinas Kesehatan Kabupaten Indragiri Hilir, di Kecamatan Tembilahan Kota ternyata Kelurahan Seberang Tembilahan memiliki kasus terbanyak dari 870 siswa sebanyak 42,4\% terinfeksi cacing Soil Transmitted helminth (STH).

Tingginya angka kejadian kecacingan di Kelurahan Seberang Tembilahan diduga karena keadaan tanah daerah ini sebagian besar terdiri dari tanah gambut dan endapan sungai dan rawa-rawa. Daerah ini digolongkan daerah beriklim tropis basah dengan udara agak lembab, selain itu Kelurahan Seberang Tembilahan merupakan daerah pasang surut. Masyarakat masih banyak Buang Air Besar (BAB) di tepi sungai, dengan kondisi ini ketika air pasang $B A B$ tentu akan terbawa ke area pemukiman sehingga kontaminasi tanah oleh tinja manusia tinggi sementara masyarakat masih banyak beraktivitas di area tersebut.

Permasalahan yang akan dibahas dalam penelitian ini terkait dengan fenomena di atas adalah: Apakah ada pengaruh faktor lingkungan fisik (sarana air bersih, kondisi jamban, kondisi SPAL, jenis lantai rumah, pengelolaan sampah RT) terhadap kecacingan pada murid sekolah dasar di Kelurahan Seberang Tembilahan Kabupaten Indragiri Hilir. Apakah ada pengaruh faktor ekonomi (penghasilan keluarga) terhadap kecacingan pada murid sekolah dasar di Kelurahan Seberang Tembilahan Kabupaten Indragiri Hilir. Apakah ada pengaruh faktor lingkungan sosial (kebersihan kuku, penggunaan alas kaki, kebiasaan mencuci tangan 


\section{SEHATI}

Jurnal Kesehatan
Vol 1, No 2, Agustus 2021, p. 63-72

e-ISSN : 2775-6963 | p-ISSN : 2775-6955

DOI: https://doi.org/10.52364/sehati.v1i2.7

pakai sabun, kebiasaan buang air besar) terhadap kecacingan pada murid sekolah dasar di Kelurahan Seberang Tembilahan Kabupaten Indragiri Hilir. Apakah ada pengaruh secara kebersamaan faktor lingkungan fisik (sarana air bersih, kondisi jamban, kondisi SPAL, jenis lantai rumah, pengelolaan sampah RT), faktor ekonomi (penghasilan keluarga) dan faktor lingkungan sosial (kebersihan kuku, penggunaan alas kaki, kebiasaan mencuci tangan pakai sabun, kebiasaan buang air besar) terhadap kecacingan pada murid sekolah dasar di Kelurahan Seberang Tembilahan Kabupaten Indragiri Hilir.

\section{METODE PENELITIAN}

Metode Penelitian yang digunakan adalah penelitian survei analitik, dengan rancangan penelitian crossectional. Metode pemeriksaan menggunakan metode metode kato katz. Pada desain peneliti ini melakukan pengukuran variabel tergantung dan variabel efek, dilakukan dengan pengumpulan data satu kali secara bersamaan dalam satu waktu (Notoatmodjo, 2007). Jenis data yang digunakan adalah data primer dan data sekunder. berupa laporan yang berkaitan dengan penderita kecacingan pada murid Sekolah Dasar (SD). Sumber data diperoleh secara langsung dengan melakukan wawancara di lokasi penelitian terhadap responden terpilih. Data primer dilakukan melalui pemeriksaan pot tinja responden di laboratorium kesehatan Kabupaten Indragiri Hilir. Populasi dalam penelitian ini adalah seluruh siswa SD di Kelurahan Seberang Tembilahan sebanyak 737 siswa sebagai populasi pada 4 sekolah dasar yang terdapat di Kelurahan Seberang Tembilahan. Besar sampel dalam penelitian ini dihitung berdasarkan perhitungan rumus estimasi proporsi dengan besar sampel sebesar 72 orang.

\section{Validitas dan Realibilitas Data}

Tidak dilakukan uji validitas dan realibilitas data kepada subjek, karena daftar pertanyaan yang ada pada kuesioner sudah mengacu kepada komponen sanitasi lingkungan berdasarkan buku pedoman kesehatan lingkungan dari Kementrian Kesehatan Republik Indonesia Nomor 03 Tahun 2014 (Kemenkes RI, 2014).

\section{Definisi Operasional Variabel}

Tabel 1. Definisi Operasional Penelitian

\begin{tabular}{|c|c|c|c|c|c|c|}
\hline No & Variabel & $\begin{array}{c}\text { Definisi } \\
\text { Operasional }\end{array}$ & Alat Ukur & Cara Ukur & Hasil Ukur & Skala \\
\hline 1 & Kecacingan & $\begin{array}{l}\text { Kejadian } \\
\text { kecacingan } \\
\text { yang dialami } \\
\text { oleh responden } \\
\text { dengan } \\
\text { ditemukannya } \\
\text { telur cacing } \\
\text { pada waktu } \\
\text { pemeriksaan } \\
\text { laboratorium }\end{array}$ & $\begin{array}{l}\text { Pot tempat } \\
\text { pengambilan } \\
\text { tinja, reagen } \\
\text { pemeriksaan } \\
\text { telur cacing, } \\
\text { mikroskop } \\
\text { dan lain-lain. }\end{array}$ & $\begin{array}{c}\text { Pemeriksaan } \\
\text { Laboratorium }\end{array}$ & $\begin{array}{l}\text { Penemuan kasus kecacingan } \\
\text { pada murid SD dengan } \\
\text { kriteria: } \\
\text { 1. Tidak } \\
\text { 2. Ya }\end{array}$ & Nominal \\
\hline 2 & $\begin{array}{l}\text { Sarana Air } \\
\text { Bersih }\end{array}$ & $\begin{array}{l}\text { Air yang } \\
\text { digunakan } \\
\text { untuk sehari- } \\
\text { hari yang } \\
\text { kualitasnya } \\
\text { memenuhi } \\
\text { syarat } \\
\text { kesehatan yang } \\
\text { dapat diminum } \\
\text { setelah dimasak }\end{array}$ & Kuesioner & Wawancara & $\begin{array}{l}\text { Adanya kondisi sumur } \\
\text { responden dengan kriteria : } \\
\text { 1. Tidak memenuhi syarat } \\
\text { 2. Memenuhi syarat : air } \\
\text { gallon, sumur gali atau } \\
\text { sumur bor, sumur pompa } \\
\text { tangan dengan syarat } \\
\text { jarak septi tank dengan } \\
\text { sumber air lebih dari } \\
\text { 10M. terdapat bak } \\
\text { penampungan air yang } \\
\text { bersih }\end{array}$ & Jominal \\
\hline
\end{tabular}


Vol 1, No 2, Agustus 2021, p. 63-72

Jurnal Kesehatan

e-ISSN : 2775-6963 | p-ISSN : 2775-6955

DOI: https://doi.org/10.52364/sehati.v1i2.7

\begin{tabular}{|c|c|c|c|c|c|c|}
\hline 3 & $\begin{array}{l}\text { Kondisi } \\
\text { Jamban }\end{array}$ & $\begin{array}{l}\text { Kondisi } \\
\text { jamban yang } \\
\text { memenuhi } \\
\text { syarat } \\
\text { kesehatan }\end{array}$ & Kuesioner & Wawancara & $\begin{array}{l}\text { Adanya kondisi jamban } \\
\text { responden dengan kriteria: } \\
\text { 1. Tidak memenuhi syarat } \\
\text { 2. Memenuhi syarat : kloset } \\
\text { dari leher angsa, jarak } \\
\text { septi tank dengan sumber } \\
\text { air lebih dari 10M, } \\
\text { tersedia air yang cukup, } \\
\text { mengalir dan tersedia } \\
\text { sabun untuk cuci tangan. }\end{array}$ & Nominal \\
\hline 4 & $\begin{array}{l}\text { Kondisi } \\
\text { Sarana }\end{array}$ & $\begin{array}{l}\text { Kondisi sarana } \\
\text { pembuangan }\end{array}$ & Kuesioner & Wawancara & $\begin{array}{l}\text { Adanya Kondisi sarana } \\
\text { SPAL dengan kriteria : }\end{array}$ & Nominal \\
\hline & Pembuangan & air limbah & & & 1. Tidak memenuhi syarat & \\
\hline & Air Limbah & $\begin{array}{l}\text { dilingkungan } \\
\text { rumah } \\
\text { responden yang } \\
\text { memenuhi } \\
\text { syarat } \\
\text { kesehatan. }\end{array}$ & & & $\begin{array}{l}\text { 2. Memenuhi syarat } \\
\text { memiliki saluran } \\
\text { pembuangan air limbah } \\
\text { yang tertutup, jarak antara } \\
\text { lubang resapan SPAL } \\
\text { dengan sumber air lebih } \\
\text { dari } 10 \mathrm{M}\end{array}$ & \\
\hline 5 & $\begin{array}{l}\text { Jenis Lantai } \\
\text { Rumah }\end{array}$ & $\begin{array}{l}\text { Jenis lantai } \\
\text { rumah } \\
\text { responden }\end{array}$ & Kuesioner & Wawancara & $\begin{array}{l}\text { Adanya kondisi lantai } \\
\text { rumah responden dengan } \\
\text { kriteria: } \\
\text { 1. Tidak memenuhi syarat } \\
\text { 2. Memenuhi syarat : lantai } \\
\text { yang tidak berdebu dan } \\
\text { basah, terbuat dari } \\
\text { semen atau keramik, } \\
\text { terbuat dari papan } \\
\text { dengan syarat tidak } \\
\text { menyentuh tanah secara } \\
\text { langsung dan lantai } \\
\text { rumah selalu dalam } \\
\text { keadaan bersih }\end{array}$ & Nominal \\
\hline 6 & $\begin{array}{l}\text { Pengelolaan } \\
\text { Sampah } \\
\text { Rumah } \\
\text { Tangga }\end{array}$ & $\begin{array}{l}\text { Dilakukannya } \\
\text { pengelolaan } \\
\text { sampah rumah } \\
\text { tangga ditandai } \\
\text { dengan } \\
\text { terdapatnya } \\
\text { tempat sampah } \\
\text { dirumah } \\
\text { responden yang } \\
\text { memenuhi } \\
\text { syarat } \\
\text { kesehatan }\end{array}$ & Kuesioner & Wawancara & $\begin{array}{l}\text { Adanya sarana pengelolaan } \\
\text { sampah dengan kriteria: } \\
\text { 1. Tidak memenuhi syarat } \\
\text { 2. Memenuhi syarat : } \\
\text { terdapat tempat sampah } \\
\text { tertutup, tempat sampah } \\
\text { terpisah, melakukan } \\
\text { pemilahan sampah, dan } \\
\text { sampah dibuang ke TPA }\end{array}$ & Nominal \\
\hline \multicolumn{7}{|c|}{ Faktor ekonomi } \\
\hline 6 & $\begin{array}{l}\text { Faktor } \\
\text { Ekonomi }\end{array}$ & $\begin{array}{l}\text { Merupakan } \\
\text { tingkatan } \\
\text { penghasilan } \\
\text { seseorang }\end{array}$ & Kuesioner & Wawancara & $\begin{array}{l}\text { 1. }<\mathrm{UMR} \\
\text { 2. }>\mathrm{UMR}\end{array}$ & Nominal \\
\hline \multicolumn{7}{|c|}{ Faktor Sosial } \\
\hline 7 & $\begin{array}{l}\text { Kebersihan } \\
\text { Kuku }\end{array}$ & $\begin{array}{l}\text { Kondisi } \\
\text { kebersihan } \\
\text { kuku } \\
\text { responden }\end{array}$ & Kuesioner & Wawancara & $\begin{array}{l}\text { Adanya kondisi kuku } \\
\text { ditinjau dari segi kebersihan } \\
\text { dengan kriteria: } \\
\text { 1. Tidak memenuhi syarat } \\
\text { 2. Memenuhi syarat: } \\
\text { memotong kuku 1x }\end{array}$ & Nominal \\
\hline
\end{tabular}


Vol 1, No 2, Agustus 2021, p. 63-72

\begin{tabular}{|c|c|c|c|c|c|c|}
\hline & & & & & $\begin{array}{l}\text { seminggu, selalu } \\
\text { membersihkan tangan } \\
\text { setelah memegang tanah, } \\
\text { mencuci air dibawah air } \\
\text { yang mengalir dan } \\
\text { mencuci tangan pakai } \\
\text { sabun }\end{array}$ & \\
\hline 8 & $\begin{array}{l}\text { Kebiasaan } \\
\text { Menggunaka } \\
\text { n Alas Kaki }\end{array}$ & $\begin{array}{l}\text { Kebiasaan } \\
\text { responden } \\
\text { menggunakan } \\
\text { alas kaki bila } \\
\text { berjalan diatas } \\
\text { tanah }\end{array}$ & Kuesioner & Wawancara & $\begin{array}{l}\text { Adanya kondisi kebiasaan } \\
\text { menggunakan alas kaki } \\
\text { dengan kriteria : } \\
\text { 1. Tidak memenuhi syarat } \\
\text { 2. Memenuhi syarat : } \\
\text { menggunakan alas kaki } \\
\text { bila menginjak tanah, } \\
\text { menggunakan alas kaki } \\
\text { yang baik dan tidak } \\
\text { menjadi sumber infeksi } \\
\text { serta selalu } \\
\text { membersihkan alas kaki } \\
\text { jika kotor }\end{array}$ & Nominal \\
\hline & $\begin{array}{l}\text { Kebiasaan } \\
\text { Mencuci } \\
\text { Tangan } \\
\text { Pakai } \\
\text { Sabun }\end{array}$ & $\begin{array}{l}\text { Kebiasaan } \\
\text { mencuci tangan } \\
\text { yang dilakukan } \\
\text { responden }\end{array}$ & Kuesioner & Wawancara & $\begin{array}{l}\text { Adanya kebiasaan mencuci } \\
\text { tangan yang dilakukan } \\
\text { responden dengan kriteria : } \\
\text { 1. Tidak memenuhi syarat } \\
\text { 2. Memenuhi syarat jika, } \\
\text { mencuci tangan dibawah } \\
\text { air yang mengalir dan } \\
\text { pakai sabun setelah BAB } \\
\text { dan BAK selama } \pm 30-40 \\
\text { detik }\end{array}$ & Nominal \\
\hline 10 & $\begin{array}{l}\text { Kebiasaan } \\
\text { Buang Air } \\
\text { Besar }\end{array}$ & $\begin{array}{l}\text { Suatu tindakan } \\
\text { atau proses } \\
\text { mahluk hidup } \\
\text { untuk } \\
\text { membuang } \\
\text { kotoran atau } \\
\text { tinja yang } \\
\text { padat atau } \\
\text { setengah padat } \\
\text { yang berasal } \\
\text { dari system } \\
\text { pencernaan } \\
\text { manusia }\end{array}$ & Kuesioner & Wawancara & $\begin{array}{l}\text { Buang Air Besar (BAB) } \\
\text { dibuang pada kloset leher } \\
\text { angsa, saluran pembuangan } \\
\text { dibuang ke septic tank, jarak } \\
\text { septic tank dengan sumber air } \\
\text { bersih lebih dari } 10 \mathrm{M} \text {, selalu } \\
\text { tersedia air yang cukup dan } \\
\text { mengalir serta sabun untuk } \\
\text { cuci tangan. }\end{array}$ & Nominal \\
\hline
\end{tabular}

\section{HASIL DAN PEMBAHASAN}

\section{Analisis bivariat}

Analisis bivariat dilakukan terhadap dua variabel yang diduga berhubungan atau berkorelasi dengan pengujian statistik (Notoatmodjo, 2010). Analisis bivariat digunakan untuk mengetahui pegaruh variabel sarana air bersih, kondisi jamban, kondisi SPAL, jenis lantai rumah, pengelolaan sampah rumah tangga, penghasilan keluarga, kebersihan kuku, penggunaan alas kaki, kebiasaan mencuci tangan pakai sabun, dan kebiasaan buang air besar terhadap kejadian kecacingan pada murid SD di Kelurahan Seberang Tembilahan Kabupaten Indragiri Hilir.

Analisis bivariat dilakukan untuk melihat hubungan antara variabel independen dan variabel dependen dengan menggunakan uji Chi-square. Besar risiko variabel independen dalam mempengaruhi variabel dependen dilakukan dengan perhitungan Odds Ratio (OR) Jika nilai $\mathrm{OR}=1$, artinya variabel yang diduga merupakan faktor risiko tidak ada pengaruhnya untuk terjadinya efek. 


\section{SEHATI}

Jurnal Kesehatan
Vol 1, No 2, Agustus 2021, p. 63-72

e-ISSN : 2775-6963 | p-ISSN : 2775-6955

DOI: https://doi.org/10.52364/sehati.v1i2.7

a. Jika nilai $\mathrm{OR}>1$, artinya variabel tersebut diduga merupakan faktor risiko untuk terjadinya efek.

b. Jika nilai $\mathrm{OR}<1$, artinya variabel tersebut merupakan faktor protektif.

\section{Analisis multivariat}

Analisis multivariat menggunakan uji Regresi Logistik Ganda dengan rumus sebagai berikut :

$Y^{\prime}=a+b_{1} X_{1}+b_{2} X_{2}+\ldots .+b_{n} X_{n}$

Keterangan:

$\mathrm{Y}^{\prime} \quad=$ Variabel dependen (nilai yang diprediksikan)

$\mathrm{X}_{1}$ dan $\mathrm{X}_{2} \quad=$ Variabel independen

a $\quad=$ Konstanta (nilai $Y^{\prime}$ apabila $X_{1}, X_{2} \ldots . . X_{n}=0$ )

$\mathrm{b}=$ Koefisien regresi (nilai peningkatan ataupun penurunan)

Analisis bivariat digunakan untuk mengetahui pegaruh variabel sarana air bersih, kondisi jamban, kondisi SPAL, jenis lantai rumah, pengelolaan sampah rumah tangga, penghasilan keluarga, kebersihan kuku, penggunaan alas kaki, kebiasaan mencuci tangan pakai sabun, dan kebiasaan buang air besar terhadap kejadian kecacingan pada murid SD di Kelurahan Seberang Tembilahan Kabupaten Indragiri Hilir. Hasil analisis bivariat tersebut dapat dilihat pada Tabel 2 sebagai berikut:

Tabel 2. Hasil Analisis Bivariat

\begin{tabular}{|c|c|c|c|c|c|c|c|c|c|}
\hline \multirow{2}{*}{$\begin{array}{l}\mathrm{N} \\
\mathrm{O}\end{array}$} & \multirow[t]{2}{*}{ Variabel } & \multicolumn{4}{|c|}{ Kecacingan } & \multirow{2}{*}{$\begin{array}{l}\text { Total } \\
(\%)\end{array}$} & \multirow[t]{2}{*}{ Pvalue } & \multirow[t]{2}{*}{ OR } & \multirow[t]{2}{*}{ CI $\quad 95 \%$} \\
\hline & & $\overline{\mathrm{Ya}}$ & $\%$ & Tidak & $\%$ & & & & \\
\hline \multirow[t]{3}{*}{1} & Sarana Air Bersih & & & & & & & & \\
\hline & $\begin{array}{l}\text { Tidak memenuhi } \\
\text { syarat }\end{array}$ & 13 & 30,2 & 30 & 69,8 & $43(100)$ & \multirow[t]{3}{*}{0,184} & \multirow[t]{3}{*}{2,7} & $0,78-9,3$ \\
\hline & Memenuhi syarat & 4 & 13,8 & 25 & 86,2 & $29(100)$ & & & \\
\hline \multirow[t]{3}{*}{2} & Kondisi Jamban & & & & & & & & \\
\hline & $\begin{array}{l}\text { Tidak memenuhi } \\
\text { syarat }\end{array}$ & 16 & 27,6 & 42 & 72,4 & $58(100)$ & \multirow[t]{3}{*}{0,163} & \multirow[t]{3}{*}{4,95} & $0,6-41,0$ \\
\hline & Memenuhi syarat & 1 & 7,1 & 13 & 92,9 & $14(100)$ & & & \\
\hline \multirow[t]{3}{*}{3} & Kondisi SPAL & & & & & & & & \\
\hline & $\begin{array}{l}\text { Tidak memenuhi } \\
\text { syarat }\end{array}$ & 14 & 24,6 & 43 & 75,4 & $57(100)$ & \multirow[t]{3}{*}{1} & \multirow[t]{3}{*}{1,3} & $0,3-5,3$ \\
\hline & Memenuhi syarat & 3 & 20 & 12 & 80 & $15(100)$ & & & \\
\hline \multirow[t]{3}{*}{4} & Jenis Lantai Rumah & & & & & & & & \\
\hline & $\begin{array}{l}\text { Tidak memenuhi } \\
\text { syarat }\end{array}$ & 1 & 50 & 1 & 50 & $2(100)$ & \multirow[t]{3}{*}{0,419} & \multirow[t]{3}{*}{3,3} & $0,2-57,0$ \\
\hline & Memenuhi syarat & 16 & 22,9 & 54 & 77,1 & $70(100)$ & & & \\
\hline \multirow[t]{3}{*}{5} & $\begin{array}{ll}\text { Pengelolaan } & \text { Sampah } \\
\text { Rumah Tangga } & \end{array}$ & & & & & & & & \\
\hline & $\begin{array}{l}\text { Tidak memenuhi } \\
\text { syarat }\end{array}$ & 17 & 23,9 & 54 & 76,1 & $71(100)$ & \multirow[t]{3}{*}{1} & \multirow[t]{3}{*}{0,76} & $0,7-0,9$ \\
\hline & Memenuhi syarat & 0 & 0 & 1 & 100 & $1(100)$ & & & \\
\hline 6 & Faktor Ekonomi & & & & & & & & \\
\hline
\end{tabular}




$\begin{array}{lcccccccc}\text { Di bawah UMR } & 13 & 22 & 46 & 78 & 59(100) & 0,49 & 0,63 & 0,16-2,4 \\ \text { Di atas UMR } & 4 & 30,8 & 9 & 69,2 & 13(100) & & & \end{array}$

7 Kebersihan Kuku

$\begin{array}{lcccccccc}\begin{array}{l}\text { Tidak memenuhi } \\ \text { syarat }\end{array} & 15 & 24,6 & 46 & 75,4 & 61(100) & 1 & 1,46 & 0,3-7,6 \\ \text { Memenuhi syarat } & 2 & 18,2 & 9 & 81,8 & 11(100) & & & \end{array}$

8 Kebiasaan Menggunakan Alas Kaki

\begin{tabular}{|c|c|c|c|c|c|c|c|c|}
\hline $\begin{array}{l}\text { Tidak memenuhi } \\
\text { syarat }\end{array}$ & 17 & 25,8 & 49 & 74,2 & $66(100)$ & \multirow[t]{3}{*}{0,32} & \multirow[t]{3}{*}{0,7} & \multirow[t]{3}{*}{$0,6-0,8$} \\
\hline Memenuhi syarat & 0 & 0 & 6 & 100 & $6(100)$ & & & \\
\hline $\begin{array}{l}\text { iasaan Mencuci } \\
\text { gan Pakai Sabun }\end{array}$ & & & & & & & & \\
\hline $\begin{array}{l}\text { Tidak } \\
\text { syarat }\end{array}$ & 16 & 23,5 & 52 & 76,5 & $68(100)$ & \multirow[t]{3}{*}{1} & \multirow[t]{3}{*}{0,92} & \multirow[t]{3}{*}{$0,09-9,5$} \\
\hline Memenuhi syarat & 1 & 25 & 3 & 75 & $4(100)$ & & & \\
\hline iasaan Buang Air & & & & & & & & \\
\hline $\begin{array}{l}\text { Tidak } \\
\text { syarat }\end{array}$ & 17 & 23,6 & 55 & 76,4 & $72(100)$ & \multirow[t]{2}{*}{-} & \multirow[t]{2}{*}{-} & \multirow[t]{2}{*}{-} \\
\hline Memenuhi syarat & 0 & 0 & 0 & 0 & 0 & & & \\
\hline
\end{tabular}

Hasil uji Chi-square seluruh variabel menunjukkan nilai $p$-value $>\alpha=0,05$. Hal ini bermakna bahwa tidak terdapat faktor risiko yang signifikan mempengaruhi kejadian kecacingan pada responden (siswa sekolah dasar). Secara rinci hasil tersebut akan dijabarkan bahwa:

\section{Pengaruh Sarana Air Bersih terhadap Kecacingan}

Hasil uji Chi-square dalam Tabel 2 menunjukkan bahwa nilai $p$-value variabel sarana air bersih sebesar $0,184>\alpha=0,05$. Hal ini bermakna bahwa tidak terdapat pengaruh sarana air bersih yang signifikan mempengaruhi kejadian kecacingan pada responden (siswa sekolah dasar). Dengan OR 2,7 mengindikasikan bahwa sarana air bersih yang tersedia dirumah responden (siswa sekolah dasar) yang tidak memenuhi syarat berpeluang 2,7 kali terjadinya kecacingan.

Air dapat mempengaruhi penularan penyakit seperti faktor melalui jalur fekal-oral apabila air yang terkontaminasi tinja memindahkan organisme penyebab penyakit secara langsung ke host baru, sehingga ketika air tersebut dikonsumsi dapat menyebabkan infeksi pada host. Cara penularan berikutnya adalah melalui water washed transmission, yaitu transmisi penyakit akibat praktik higiene yang buruk karena jumlah air yang tidak cukup untuk mencuci, dengan langkanya kuantitas air, maka sulit bagi seseorang untuk menjaga kebersihan tangan, kebersihan makanan dan lingkungan sekitar (Isa, 2013).

\section{Pengaruh Kondisi Jamban terhadap Kecacingan}

Hasil uji Chi-square dalam Tabel 2 menunjukkan bahwa nilai $p$-value variabel kondisi jamban sebesar $0,163>\alpha=0,05$. Hal ini bermakna bahwa tidak terdapat pengaruh kondisi jamban yang signifikan mempengaruhi kejadian kecacingan pada responden (siswa sekolah dasar). Dengan OR 4,94 mengindikasikan bahwa kondisi jamban yang tersedia dirumah responden (siswa sekolah dasar) yang tidak memenuhi syarat berpeluang 4,95 kali terjadinya kecacingan.

Dampak buruk jamban terhadap penularan penyakit, menyangkut transmisi penyakit dari tinja. Berbagai penyakit menular seperti hepatitis A, polio, kholera, kecacingan dan lainnya merupakan penyakit yang terkait dengan akses penyediaan jamban. Fungsi jamban dari aspek kesehatan lingkungan antara lain dapat mencegah berkembangnya berbagai penyakit yang disebabkan oleh kotoran manusia. Sementara dampak serius membuang kotoran di sembarang tempat menyebabkan pencemaran tanah, air dan udara 


\section{SEHATI}

Jurnal Kesehatan
Vol 1, No 2, Agustus 2021, p. 63-72

e-ISSN : 2775-6963 | p-ISSN : 2775-6955

DOI: https://doi.org/10.52364/sehati.v1i2.7

karena menimbulkan bau. Pembuangan tinja yang tidak dikelola dengan baik berdampak mengkawatirkan terutama pada kesehatan dan kualitas air untuk rumah tangga maupun keperluan komersial (Kusnoputranto. 2011).

\section{Pengaruh Kondisi Sarana Pembuangan Air Limbah (SPAL) terhadap Kecacingan}

Hasil uji Chi-square dalam Tabel 2 menunjukkan bahwa nilai $p$-value variabel kondisi sarana pembuangan air limbah (SPAL) sebesar $1>\alpha=0,05$. Hal ini bermakna bahwa tidak terdapat pengaruh kondisi sarana pembuangan air limbah (SPAL) yang signifikan mempengaruhi kejadian kecacingan pada responden (siswa sekolah dasar). Dengan OR 1,3 mengindikasikan bahwa kondisi sarana pembuangan air limbah (SPAL) yang tersedia dirumah responden (siswa sekolah dasar) yang tidak memenuhi syarat berpeluang 1,3 kali terjadinya kecacingan.

Air buangan yang dibuang tidak saniter dapat menjadi media perkembangan mikroorganisme patogen, larva nyamuk ataupun serangga yang dapat menjadi media transmisi penyakit kolera, typus abdominalis, disentri baciler kecacingan dan sebagainya. Cara pembuangan air limbah rumah tangga yang terbaik adalah melalui saluran tertutup atau yang biasa disebut Saluran Pembuangan Air Limbah (SPAL). SPAL yang memenuhi syarat kesehatan yaitu tertutup, kedap air dan mengalir lancar (Fitri, et all. 2012).

\section{Pengaruh Jenis Lantai Rumah terhadap Kecacingan}

Hasil uji Chi-square dalam Tabel 2 menunjukkan bahwa nilai $p$-value variabel jenis lantai rumah sebesar $0,419>\alpha=0,05$. Hal ini bermakna bahwa tidak terdapat pengaruh jenis lantai rumah yang signifikan mempengaruhi kejadian kecacingan pada responden (siswa sekolah dasar). Dengan OR 3,3 mengindikasikan bahwa jenis lantai rumah yang tersedia dirumah responden (siswa sekolah dasar) yang tidak memenuhi syarat berpeluang 1,3 kali terjadinya kecacingan.

\section{Pengaruh Pengelolaan Sampah Rumah Tangga terhadap Kecacingan}

Hasil uji Chi-square dalam Tabel 2 menunjukkan bahwa nilai $p$-value variabel pengelolaan sampah rumah tangga sebesar $1>\alpha=0,05$. Hal ini bermakna bahwa tidak terdapat pengaruh pengelolaan sampah rumah tangga yang signifikan mempengaruhi kejadian kecacingan pada responden (siswa sekolah dasar). Dengan OR 0,76 mengindikasikan bahwa pengelolaan sampah rumah tangga dirumah responden (siswa sekolah dasar) yang tidak memenuhi syarat berpeluang 0,76 kali terjadinya kecacingan.

Sampah adalah semua benda atau produk sisa dalam bentuk padat sebagai akibat aktivitas manusia yang dianggap tidak bermanfaat dan tidak dikehendaki oleh pemiliknya atau dibuang sebagai barang tidak berguna. Gangguan yang ditimbulkan oleh sampah antara lain adalah pencemaran lingkungan karena sampah yang dibuang sembarangan dalam kurun waktu tertentu akan membusuk dan hasil penguraian sampah organik berupa cairan dan gas akan mencemari tanah, air dan udara, serta gas yang dihasilkan berbau busuk menyengat akan mencemari udara. Dampak lain dari pengolahan sampah yang tidak baik adalah akan memudahkan membantu penularan penyakit seperti diare. typhus, cholera, disentri dan lainlain. Selain lalat, binatang penular penyakit lainnya seperti kecoa, nyamuk, tikus dan lain-lain akan berkembang biak pada sampah yang tentunya akan menularkan penyakit kepada kita yang tinggal disekitar sampah, termasuk dalam waktu yang lama bisa menyebabkan terjadinya penyakit menular lain (Chandra, 2007).

\section{Pengaruh Faktor Ekonomi (Penghasilan Keluarga) terhadap Kecacingan}

Hasil uji Chi-square dalam Tabel 2 menunjukkan bahwa nilai $p$-value variabel faktor ekonomi (penghasilan keluarga) sebesar $0,49>\alpha=0,05$. Hal ini bermakna bahwa tidak terdapat pengaruh faktor ekonomi (penghasilan keluarga) yang signifikan mempengaruhi kejadian kecacingan pada responden (siswa sekolah dasar). Dengan OR 0,49 mengindikasikan bahwa faktor ekonomi (penghasilan keluarga) responden (siswa sekolah dasar) yang tidak memenuhi syarat berpeluang 0,49 kali terjadinya kecacingan.

\section{Pengaruh Kebersihan Kuku terhadap Kecacingan}

Hasil uji Chi-square dalam Tabel 2 menunjukkan bahwa nilai p-value variabel kebersihan kuku sebesar $1>\alpha=0,05$. Hal ini bermakna bahwa tidak terdapat pengaruh kebersihan kuku yang signifikan mempengaruhi kejadian kecacingan pada responden (siswa sekolah dasar). Dengan OR 1,46 mengindikasikan bahwa kebersihan kuku responden (siswa sekolah dasar) yang tidak memenuhi syarat berpeluang 1,46 kali terjadinya kecacingan.

\section{Pengaruh Kebiasaan Menggunakan Alas Kaki terhadap Kecacingan}

Hasil uji Chi-square dalam Tabel 2 menunjukkan bahwa nilai p-value variabel kebiasaan menggunakan alas kaki sebesar $0,32>\alpha=0,05$. Hal ini bermakna bahwa tidak terdapat pengaruh 


\section{SEHATI}

Jurnal Kesehatan
Vol 1, No 2, Agustus 2021, p. 63-72

e-ISSN : 2775-6963 | p-ISSN : 2775-6955

DOI: https://doi.org/10.52364/sehati.v1i2.7

kebiasaan menggunakan alas kaki yang signifikan mempengaruhi kejadian kecacingan pada responden (siswa sekolah dasar). Dengan OR 0,7 mengindikasikan bahwa kebiasaan menggunakan alas kaki responden (siswa sekolah dasar) yang tidak memenuhi syarat berpeluang 0,7 kali terjadinya kecacingan.

\section{Pengaruh Kebiasaan Mencuci Tangan Pakai Sabun terhadap Kecacingan}

Hasil uji Chi-square dalam Tabel 2 menunjukkan bahwa nilai $p$-value variabel kebiasaan mencuci tangan pakai sabun sebesar $1>\alpha=0,05$. Hal ini bermakna bahwa tidak terdapat pengaruh kebiasaan mencuci tangan pakai sabun yang signifikan mempengaruhi kejadian kecacingan pada responden (siswa sekolah dasar). Dengan OR 0,92 mengindikasikan bahwa kebiasaan mencuci tangan pakai sabun responden (siswa sekolah dasar) yang tidak memenuhi syarat berpeluang 0,92 kali terjadinya kecacingan.

\section{Pengaruh Kebiasaan Buang Air Besar terhadap Kecacingan}

Hasil uji Chi-square dalam Tabel 2 menunjukkan bahwa nilai $p$-value variabel kebiasaan buang air besar tidak memiliki nilai. Hal ini karena seluruh responden memiliki kebiasaan buang air besar yang tidak memenuhi syarat.

\section{Hasil Analisis Multivariat}

Hasil analisis bivariat diketahui bahwa tidak terdapat faktor risiko yang signifikan mempengaruhi kejadian kecacingan pada responden, sehingga dilakukan seleksi bivariat sebagai berikut:

Tabel 3. Seleksi Bivariat

\begin{tabular}{clccc}
\hline No & \multicolumn{1}{c}{ Variabel } & Pvalue & OR & Keterangan \\
\hline 1 & Sarana Air Bersih & 0,184 & 2,7 & Lanjut multivariat \\
2 & Kondisi Jamban & 0,163 & 4,95 & Lanjut multivariat \\
3 & Kondisi SPAL & 1 & 1,3 & Tidak Lanjut multivariat \\
4 & Jenis Lantai Rumah & 0,419 & 3,3 & Tidak Lanjut multivariat \\
5 & Pengelolaan Sampah Rumah Tangga & 1 & - & Tidak Lanjut multivariat \\
6 & Faktor Ekonomi & 0,490 & 0,63 & Tidak Lanjut multivariat \\
7 & Kebersihan Kuku & 1 & 1,46 & Tidak Lanjut multivariat \\
8 & Kebiasaan Menggunakan Alas Kaki & 0,320 & - & Tidak Lanjut multivariat \\
9 & Kebiasaan Mencuci Tangan Pakai Sabun & 1 & 0,92 & Tidak Lanjut multivariat \\
10 & Kebiasaan Buang Air Besar & - & - & Tidak Lanjut multivariat \\
\hline
\end{tabular}

Terdapat dua variabel yang memiliki nilai pvalue $<0,25$ yaitu sarana air bersih dan kondisi jamban. Oleh karena itu kedua variabel tersebut dilakukan analisis secara bersamaan dan diperoleh hasil sebagai berikut:

Tabel 4. Model Awal (Analisis Secara Bersamaan)

\begin{tabular}{lllll}
\hline No & Variabel & Pvalue & OR Bivariat & aOR \\
\hline 1 & Sarana Air Bersih & 0,206 & 2,7 & 2,26 \\
2 & Kondisi Jamban & 0,204 & 4,95 & 4,01 \\
\hline
\end{tabular}

Dengan menggunakan metode ENTER yaitu dengan memasukan seluruh variabel pada tahap awal dan kemudian dikeluarkan satu persatu yang tidak signifikan serta melihat perubahan OR nya. Pada model awal, variabel sarana air bersih dikeluarkan dari model sehingga diperoleh hasil sebagai berikut: 
Tabel 5. Model Setelah Dikeluarkannya Variabel Sarana Air Bersih

\begin{tabular}{cccccc}
\hline No & Variabel & Pvalue & $\begin{array}{c}\text { OR model } \\
\text { awal }\end{array}$ & OR baru & Perubahan OR (\%) \\
\hline 1 & Kondisi Jamban & 0,138 & 4,01 & 4,95 & 23,4 \\
\hline
\end{tabular}

Setelah variabel sarana air bersih dikeluarkan, terdapat perubahan OR yang lebih dari $10 \%$ pada variabel kondisi jamban. Sehingga variabel sarana air bersih dimasukan kembali ke model. Selanjutnya variabel kondisi jamban dikeluarkan dari model sehingga diperoleh hasil sebagai berikut:

Tabel 6. Model Setelah Dikeluarkannya Variabel Kondisi Jamban

\begin{tabular}{cccccc}
\hline No & Variabel & Pvalue & $\begin{array}{c}\text { OR model } \\
\text { awal }\end{array}$ & OR baru & Perubahan OR (\%) \\
\hline 1 & Sarana air bersih & 0,115 & 2,26 & 2,7 & 19,4 \\
\hline \multicolumn{5}{c}{ Setelah variabel kondisi jamban dikeluarkan, terdapat perubahan OR yang lebih dari $10 \%$ pada } \\
variabel sarana air bersih. Sehingga variabel kondisi jamban dimasukan kembali ke model. \\
Tabel 7. Model Akhir Setelah Dimasukkannya Kembali Variabel Sarana Air Bersih dan Kondisi Jamban \\
\hline No & Variabel & Pvalue & OR Bivariat & aOR & CI \\
\hline 1 & Sarana Air Bersih & 0,206 & 2,7 & 2,26 & $0,63-8,05$ \\
2 & Kondisi Jamban & 0,204 & 4,95 & 4,01 & $0,47-34,26$ \\
\hline
\end{tabular}

Dari analisis tersebut maka persamaan regresi logistik yang diperoleh, yaitu: $\mathrm{Y}=-2,930+0,820$ (Sarana Air Bersih) $+1,389$ (Kondisi Jamban)

Aplikasi persamaan tersebut digunakan untuk memprediksi probabilitas seseorang untuk mengalami kecacingan, apabila:

Seseorang dengan penyediaan sarana air bersih dan kondisi jamban yang buruk maka probabilitasnya adalah $\mathrm{Y}=-2,930+0,820+1,389(1)$

$$
\begin{array}{ll}
\mathrm{Y} & =-0,721 \\
\mathrm{P} & =1 /\left(1+2,7183^{-(-0,721)}\right) \\
\mathrm{P} & =1 /(1+1,970) \\
\mathrm{P} & =0,337
\end{array}
$$

Maka probabilitas seseorang untuk mengalami kecacingan sebesar 33,7\%.

Seseorang dengan penyediaan sarana air bersih dan kondisi jamban yang baik maka probabilitasnya

$\begin{array}{rlll}\text { adalah } \mathrm{Y} & = & -2,930+0,820+1,389(0) \\ \mathrm{Y} & = & -0,721 \\ \mathrm{P} & = & 1 /\left(1+2,7183^{-(-2,930)}\right) \\ \mathrm{P} & = & 1 /(1+7,965) \\ \mathrm{P} & = & 0\end{array}$

Maka probabilitas seseorang untuk mengalami kecacingan sebesar $0 \%$.

Kejadian kecacingan yang terjadi pada murid SD di Kelurahan Seberang Tembilahan Kabupaten Indragiri Hilir lebih dominan-dipengaruhi oleh penyediaan sarana air bersih dan kondisi jamban yang buruk.

\section{KESIMPULAN}

Berdasarkan hasil penelitian dan pembahasan pada bab sebelumnya, maka dapat disimpulkan bahwa Faktor lingkungan fisik (sarana air bersih, kondisi jamban, kondisi SPAL, jenis lantai rumah, pengelolaan sampah RT) tidak berpengaruh terhadap kecacingan pada murid sekolah dasar di Kelurahan Seberang Tembilahan Kabupaten Indragiri Hilir. Faktor ekonomi (penghasilan keluarga) tidak berpengaruh terhadap kecacingan pada murid sekolah dasar di Kelurahan Seberang Tembilahan 


\section{SEHATI}

Jurnal Kesehatan
Vol 1, No 2, Agustus 2021, p. 63-72

e-ISSN : 2775-6963 | p-ISSN : 2775-6955

DOI: https://doi.org/10.52364/sehati.v1i2.7

Kabupaten Indragiri Hilir. Faktor lingkungan sosial (kebersihan kuku, penggunaan alas kaki, kebiasaan mencuci tangan pakai sabun, kebiasaan buang air besar) tidak berpengaruh terhadap kecacingan pada murid sekolah dasar di Kelurahan Seberang Tembilahan Kabupaten Indragiri Hilir. Secara kebersamaan faktor lingkungan fisik (sarana air bersih, kondisi jamban, kondisi SPAL, jenis lantai rumah, pengelolaan sampah RT), faktor ekonomi (penghasilan keluarga) dan faktor lingkungan sosial (kebersihan kuku, penggunaan alas kaki, kebiasaan mencuci tangan pakai sabun, kebiasaan buang air besar) tidak berpengaruh terhadap kecacingan pada murid sekolah dasar di Kelurahan Seberang Tembilahan Kabupaten Indragiri Hilir.

\section{UCAPAN TERIMAKASIH}

Ucapan terima kasih penulis sampaikan kepada pihak sekolah dasar di Kelurahan Seberang Tembilahan Kabupaten Indragiri Hilir yang telah memberikan data dan informasi sehingga terlaksananya penelitian ini di lapangan.

\section{DAFTAR PUSTAKA}

Chandra, B. 2007. Pengantar Kesehatan Lingkungan. Penerbit Buku Kedokteran EGC. Jakarta.

Fitri, Arif, Iqbal M. 2012. Faktor Risiko Terjadinya Kecacingan pada Anak Sekolah Dasar di Kelurahan Pannampu Kec. Tallo Tapanuli Selatan. Airlangga University Library. Surabaya.

Isa, R. 2013. Hubungan antara Higiene Perorangan dan Sanitasi Lingkungan dengan Kejadian Infeksi Cacing pada Siswa SD Negeri Jagabaya 1 Warunggunung Kabupaten Lebak Provinsi Banten Tahun 2013. Tesis. Universitas Indonesia.

Kusnoputranto, H. 2011. Dasar-Dasar Kesehatan Lingkungan. FKM UI. Jakarta.

Notoatmodjo, 2007. Promosi Kesehatan dan Ilmu Perilaku. Rineka Cipta. Jakarta.

Notoatmodjo, 2010. Metodologi Penelitian Kesehatan. Rineka Cipta. Jakarta.

Kementrian Kesehatan Republik Indonesia Nomor 424 Tahun 2006 tentang Pedoman Pengendalian Cacingan.

Kementrian Kesehatan Republik Indonesia Nomor 03 Tahun 2014 tentang Pedoman Kesehatan Lingkungan. 